\title{
EKONOMI ISLAM DALAM KAJIAN FIQH KONTEMPORER; STUDI AWAL TENTANG JAMINAN FIDUSIA
}

\author{
Wazin Baihaqi \\ IAIN Sultan Maulana Hasanuddin Banten
}

Abstrak. Ekonomi Islam Dalam Kajian Fiqh Kontemporer Studi Awal Tentang Jaminan Fidusia. Studi Awal Tentang Jaminan Fidusia Dalam Kajian Fiqh Kontemporer Ekonomi Islam. tujuan utama hukum dalam Islam adalah untuk kemaslahatan ummat. kemaslahatan tersebut diukur dengan doktrin ushul fiqh yang dikenal dengan sebutan al kulliyatul kahms atau maqashid syariah. Salah satu tujuan dari hukum Islam adalah hifdz al-mal yaitu memelihara dan menjamin kepemilikan harta benda. Pelaksanaan hukum ekonomi untuk mengatur segala kegiatan ekonomi haruslah dapat dipastikan memberi kemanfaatan bagi ummat Islam. Oleh karena itu, Islam memberikan aturan-aturan dalam muamalah seperti jual beli, sewa-menyewa, gadai dan sebagainya. Kini bentuk transaksi ekonomi semakin beragam, salah satunya adalah bentuk jaminan fidusia. Fidusia merupakan bentuk jaminan yang dipraktekkan di Belanda kemudian diadopsi oleh sistem hukum di Indonesia sejak zaman kolonialisme hingga sekarang. Jaminan fidusia semakin populer digunakan sebagai perjanjian ikutan dalam transaksi pembiayaan, karena barang jaminan tetap dalam penguasaan pemberi jaminan sehingga memberi kemudahan bagi pemberi jaminan untuk memanfaatkan barang jaminan. Model jaminan seperti ini tidak banyak dibahas dalam fiqh muamalah klasik walaupun beberapa fuqaha telah membahasnya. Sebagai respon dari perkembangan transaksi ekonomi, perlu kiranya praktek jaminan fidusia ini diangkat dalam wacana perspektif hukum ekonomi Islam. Dengan pertimbangan kemaslahatan ummat agar terhindar dari transaksi ekonomi yang mengandung Maisir, Gharar, Haram, Riba, dan Bathil. Oleh karena itu, Dewan Syari'ah Nasional (DSN) mengeluarkan fatwa Nomor 68/DSN-MUI/III/2008 tentang rahn tasjily yang memiliki bentuk perjanjaian yang hampir sama dengan jaminan fidusia namun tetap memenuhi kaidah-kaidah fiqh muamalah.

Kata Kunci: Ekonomi Islam,Fiqh Kontemporer, Jaminan Fidusia.

Abstract. Preliminary Study on Fiduciary in Fiqh Contemporary of Islamic Economics Studies. The main purpose of Islamic law is for the benefit of the people. The benefit is measured by the jurisprudence usul doctrine known as al kulliyatul kahms or sharia maqashid. One of the goals of Islamic law is hifdz al-mal (to maintain and guarantee of property ownership). The implementation of economic law to regulate all economic activities should be ensured to give benefits to Muslims. Therefore, Islam provides the rules of muamalah in commercing, leasing, fiduciary, etc. Nowadays, the diversity forms of economic transactions increasing rapidly, one of them is fiduciary. Fiduciary is a form of guarantee that adopted by the legal system of law in Indonesia from Netherlands since the colonial era to the present. Fiduciary guarantee begins popular used as a follow-up agreement on financing transactions; this is because the 
Islamiconomic: Jurnal Ekonomi Islam Vol.7 No.2 Juli - Desember 2016

collateral still handling in the guarantor, also provide the convenience for the guarantor to take the advantage from the collateral. This model almost not discussed in the classical fiqh muamalah although some jurists have discussed about it. As the response of the development of economic transactions, it would need to practice more about the fiduciary in the discourse perspective of Islamic economics law. In order to avoid the Maisir, Gharar, Haram, and Riba in Islamic transactions, therefore, the National Sharia Council (DSN) issued the fatwa Number. 68 /DSN-MUI/III/2008 about the Rahn Tasjily that similar to the fiduciary while still complying with the rules of fiqh muamalah.

Keywords: Islamic Economics, Fiqh Contemporary, Fiduciary.

\section{Pendahuluan}

Perkembangan ekonomi Islam baik dalam wacana maupun dalam praktek terus mengalami perubahan. Praktek-praktek ekonomi berkembang lebih kompleks dan beragam. Pada tahap inilah sangat diperlukan agar praktek ekonomi tetap sesuai dengan syari'at Islam. Diperlukan aturan-aturan hukum yang baru dan diperbaharui agar dapat mengatasi masalah-masalah ekonomi. Hukum akan kehilangan eksistensi dan fungsinya jika tidak mampu mengatasi masalah yang terjadi di masyarakat. Demikan juga dengan hukum ekonomi Islam, jika bergeming seputar transaksitransaksi ekonomi yang dibahas dalam fiqh muamalah klasik, maka akan kehilangan eksistensinya dan tergerus arus perubahan jaman.

Untuk tetap responsif terhadap perkembangan transaksi ekonomi kekinian, hukum ekonomi Islam selayaknya melakukan usaha ijtihadi dengan mengakomodasi kegiatan ekonomi mutakhir namun tetap analitis untuk mengkritisi dan memberikan solusi agar semua kegiatan ekonomi tetap dalam koridor hukum ekonomi Islam (Fiqh Muamalah). Salah satu bentuk transaksi ekonomi kekinian yang memerlukan usaha ijtihadi dalam fiqh muamalah adalah lembaga jaminan. Masalah jaminan sebenarnya merupakan insitusi yang sudah mapan dalam teori dan praktek ekonomi Islam. Bahkan dasar hukum jaminan memiliki dasar yang kuat dalam Al Qur'an dan Sunnah. Namun lembaga jaminan fidusia yang kini populer diberlakukan dalam beberapa lembaga keuangan secara historis bukanlah berasal dari tradisi khasanah keilmuan hukum Islam.

Pertumbuhan ekonomi tidak terlepas dari aspek jaminan. Bahkan Pemerintah menggunakan lembaga jaminan sebagai sarana untuk meningkatkan dan membangun dunia usaha. Tersedianya dana perlu diimbangi dengan ketentuan hukum yang 
Wazin: Ekonomi Islam Dalam Kajian...

lengkap dan jelas yang mengatur mengenai lembaga jaminan. Jaminan fidusia sebagai salah satu bentuk lembaga jaminan pada awalnya kurang memiliki kepastian hukum karena hanya didasarkan pada yurisprudensi. Dengan diberlakukannya UU No. 42 Tahun 1999, jaminan fidusia lebih memiliki kepastian hukum dan banyak dipergunakan oleh lembaga keuangan seperti Bank dan Perusahaan Pembiayaan. Jaminan fidusia merupakan solusi tepat bagi masyarakat ketika mereka membutuhkan dana, karena barang jaminan tetap berada pada penguasaan pemberi jaminan. Dengan jaminan fidusia masyarakat tetap dapat menggunakan barang jaminan untuk keberlangsungan usahanya. Fasilitas jaminan fidusia banyak digunakan oleh berbagai kalangan menengah ke bawah karena dana pinjaman yang relatif kecil.

Indonesia dengan mayoritas muslim tentu sangat berkepentingan untuk mempertanyakan bagaimanakah kedudukan hukum jamnan fidusia dalam perspektif fiqh muamalah. Dalam tahap inilah diperlukan usaha ijtihadi untuk mencari bentuk jaminan yang sesuai dengan kaidah fiqh muamalah. Dengan diputuskannya fatwa Nomor 68/DSN-MUI/III/2008 tentang rahn tasjily yang sejalan dengan bentuk jaminan fidusia, namun dengan memperhatikan kaidah fiqh muamalah, masyarakat muslim Indonesia dapat memanfaatkan pinjaman dengan jaminan yang sesuai dengan koridor hukum Islam.

\section{Hukum Ekonomi Islam Dalam Maqashid Syariah}

Kemaslahatan ummat (kemanfaatan yang baik bagi ummat) merupakan tujuan hukum Islam. Kemaslahatan menurut pengertiannya yang asli adalah memelihara sesuatu yang dimaksud oleh syari'at yaitu agama, jiwa, akal, keturunan dan harta. Sesuatu yang dapat merusak lima perkara disebut mafsadat. ${ }^{1}$ Ukuran kemaslahatan mengacu pada doktrin ushul fiqh yang dikenal dengan sebutan al kulliyatul kahms (lima pokok pilar) atau dengan kata lain disebut dengan yang terdiri dari: ${ }^{2}$

1. Hifdz al-dien (menjamin kebebasan beragama).

2. Hifdz al- nafs (memelihara kelangsungan hidup)

3. Hifdz al-aql (menjamin kreatifitas berfikir)

4. Hifdz al-nasl (menjamin keturunan dan kehormatan)

5. Hifdz al-mal (menjamin kepemilikan harta, property dan kekayaan). 
Islamiconomic: Jurnal Ekonomi Islam Vol.7 No.2 Juli - Desember 2016

Al kulliyatul kahms disebut juga dengan maqashid asy-syariah. Secara bahasa maqashid syari'ah terdiri dari dua kata yaitu maqashid dan syari'ah. Maqashid berarti kesengajaan atau tujuan, maqashid merupakan bentuk jamak dari maqsud yang berasal dari suku kata Qashada yang berarti menghendaki atau memaksudkan. Maqashid berarti hal-hal yang dikehendaki dan dimaksudkan. ${ }^{3}$ Sedangkan Syari'ah secara bahasa berarti المواضع تحدر الي الماءartinya jalan menuju sumber air. Jalan menuju sumber air dapat juga diartikan berjalan menuju sumber kehidupan. ${ }^{4}$ Maqashid Syariah secara istilah adalah tujuan-tujuan syariat Islam yang terkandung dalam setiap aturannya. Maqashid Syari'ah adalah konsep untuk mengetahui hikmah (nilai-nilai dan sasaran syara' yang tersurat dan tersirat dalam Al-Qur'an dan Hadits). yang ditetapkan oleh Allah ta'ala terhadap manusia adapun tujuan akhir hukum tersebut adalah satu, yaitu mashlahah atau kebaikan dan kesejahteraan umat manusia baik di dunia (dengan Mu'amalah) maupun di akhirat (dengan 'aqidah dan Ibadah). Jika ummat Islam mengabaikan maqashid al-syari'ah (tujuan-tujuan univesal syari'ah) maka runtuhlah nilai-nilai Islam yang substansial 5 .

Secara umum tujuan syariat Islam dalam menetapkan hukum-hukumnya adalah untuk kemaslahatan manusia seluruhnya, baik kemaslahatan di dunia maupun kemashlahatan di akhirat. Hal ini berdasarkan Firman Allah ta'ala:

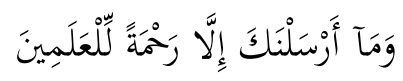

Artinya: Dan tiadalah kami mengutus kamu, melainkan untuk (menjadi) rahmat bagi semesta alam. QS. Al-Anbiya (21): 107.

Selanjutnya di dalam Al Qur'an, Surat Al Baqarah (2): 201-202 tertulis

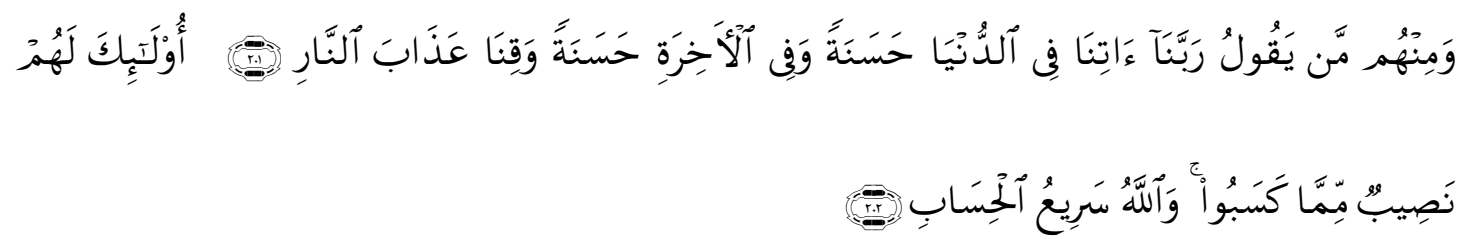


Wazin: Ekonomi Islam Dalam Kajian...

Artinya: Dan di antara mereka ada orang yang bendoa: "Ya Tuhan Kami, berilah Kami kebaikan di dunia dan kebaikan di akhirat dan peliharalah Kami dari siksa neraka".

Mereka Itulah orang-orang yang mendapat bahagian daripada yang mereka usahakan; dan Allah sangat cepat perhitungan-Nya. Q.S. Al Baqarah (2); 201202

Salah satu tujuan dari hukum Islam adalah hifdz al-mal yaitu memelihara dan menjamin kepemilikan harta benda. Pelaksanaan hukum ekonomi yang mengatur kegiatan ekonomi haruslah dapat dipastikan memberi kemanfaatan bagi ummat Islam terutama untuk memelihara hifdz al-mal (menjamin kepemilikan harta benda. Islam meyakini bahwa semua harta di dunia ini adalah milik Allah Ta'ala, manusia hanya berhak untuk memanfaatkannya saja. Namun terkadang untuk memenuhi kebutuhan masing-masing terjadi konflik dan perilaku tidak adil serta persaingan yang tidak sehat antara sesama dalam memenuhi kebutuhan-kebutuhannya. Untuk ini Islam mensyariatkan peraturan-peraturan mengenai muamalah seperti jual beli, sewa-menyewa, gadai dan sebagainya. Salah satu kaidah muamalah dalam Islam diantaranya adalah bahwa transaksi ekonomi tidak boleh mengandung unsru maisir, gharar, haram riba dan bathil.

Perlindungan Islam terhadap harta benda seseorang tercermin dalam firmanNya Al Qur'an Surat An-Nisaa (4): 29-32

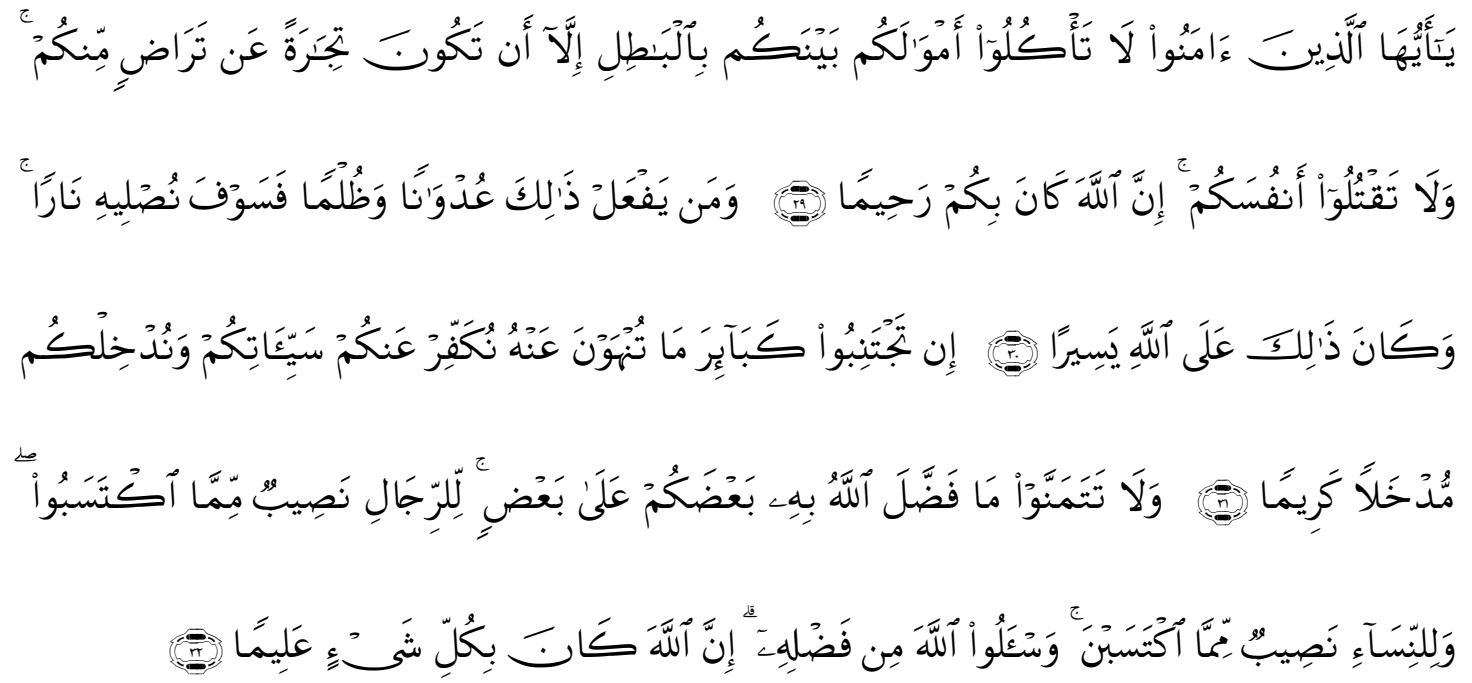


Islamiconomic: Jurnal Ekonomi Islam Vol.7 No.2 Juli - Desember 2016

Artinya: Hai orang-orang yang beriman, janganlah kamu saling memakan harta sesamamu dengan jalan yang batil, kecuali dengan jalan perniagaan yang Berlaku dengan suka sama-suka di antara kamu. dan janganlah kamu membunuh dirimu. Sesungguhnya Allah adalah Maha Penyayang kepadamu. Dan Barangsiapa berbuat demikian dengan melanggar hak dan aniaya, Maka Kami kelak akan memasukkannya ke dalam neraka. yang demikian itu adalah mudah bagi Allah. Jika kamu menjauhi dosa-dosa besar di antara dosa-dosa yang dilarang kamu mengerjakannya, niscaya Kami hapus kesalahankesalahanmu (dosa-dosamu yang kecil) dan Kami masukkan kamu ke tempat yang mulia (surga). Dan janganlah kamu iri hati terhadap apa yang dikaruniakan Allah kepada sebahagian kamu lebih banyak dari sebahagian yang lain. (karena) bagi orang laki-laki ada bahagian dari pada apa yang mereka usahakan, dan bagi Para wanita (pun) ada bahagian dari apa yang mereka usahakan, dan mohonlah kepada Allah sebagian dari karunia-Nya. Sesungguhnya Allah Maha mengetahui segala sesuatu.(Q.S. An-Nisaa(4): 9232.

\section{Hukum Jaminan Dalam Sistem Hukum Islam}

Al Qur'an sebagai sumber hukum Islam yang utama terbagi dalam 2 bagian yaitu: muhkam (terang) dan mutasyabih (samar). Hukum yang mutasyabih inilah yang memerlukan penafisran lebih lanjut. Pada masa Nabi Muhammad ayat-ayat Al Qur'an yang mutasyabihat ditetapkan dalam Sunnah (ucapan dan perbuatan Nabi). Penjelasan- penjelasan Nabi tersebut terikat oleh dimensi waktu, tempat, situasi dan kultur sehingga penjelasan Rasulallah dilanjutkan melalui pengkajian-pengkajian dan penelitian ijtihadi 6 .

Secara teknis ijtihad berarti meneruskan setiap usaha untuk menentukan sedikit banyaknya kemungkinan suatu persoalan syari'at . Ijtihad merupakan proses penafsiran dan penafsirn kembali ayat-ayat yang diwahyukan dan sebagian pada deduksi analogis dan penalaran. Kehidupan dari zaman ke zaman selalu berubah dengan masalah-masalah yang lebih kompleks. Dengan proses ijtihad, hukum Islam berkembang mengikuti perubahan. Usaha ijtihad dalam hal ini amat diperlukan 
Wazin: Ekonomi Islam Dalam Kajian...

untuk menciptakan model-model dan teori-teori yang dapat menjawab persoalan aktual tetapi dengan tetap menyelaraskan diri pada Al Qur'an dan Sunnah.

Proses ijtihad memerlukan diberikannya prioritas masing-masing hukum sesuai dengan statusnya. Dalam memecahkan suatu persoalan hukum mujtahid pertama-tama harus mencari keterangan dalam Al Qur'an dan Sunnah. Jika jawabannya tidak terdapat di dalamnya barulah ia menempuh ijma (konsensus) masyarakat dan akhirnya harus melakukan ijtihad. Syarat penting yang harus dimiliki dalam melakukan ijtihad adalah kemampuan dan pengetahuan yang baik tentang perintah-perintah dalam Al Qur'an dan Sunnah. Dengan demikian dapat dikatakan bahwa ijtihad merupakan usaha memecahkan masalah kontemporer dengan tidak meninggalkan ketentuan Al Q ur'an, Sunnah dan ijma.

Qiyas merupakan usaha untuk mengembalikan atau mempersamakan suatu kejadian yang tidak ada ketentuan nash, dengan kejadian lain yang sudah ada ketentuan hukum dalam nash, karena ada illat (sebab) yang bisa diidentifikasi. Qiyas sangat diperlukan ketika perubahan banyak terjadi pada setiap zaman, seperti apakah bunga bank sama dengan riba dan sebagainya.

Dengan kerangka hukum yang lengkap Islam membuktikan dirinya sebagai agama yang bukan hanya berkutat di tataran normatif. Al Qur'an dan sunnah adalah nilai-nilai absolut yang melampaui dimensi waktu. Ijma merupakan upaya penafsiran Al Qur'an dan Sunnah dalam bentuk konsensus yang disepakati tentang suatu hukum. Adapun ijtihad dan qiyas merupakan bentuk operasional yang terikat dengan konteks waktu dan ruang yang berubah, dengan tetap berpijak pada nilai absolut (Al Qur'an dan Sunnah). Justru dengan ijtihad dan qiyas Islam memiliki kerangka hukum yang lentur (elastis) sehingga sangat responsif terhadap gejala masyarakat yang berubah-ubah.

Pada wilayah ijtihad dan qiyas diperlukan pengamatan atas gejala-gejala yang timbul dalam masyarakat (termasuk gejala ekonomi). Sehingga pada tahap ini ekonomi Islam ada pada tataran positif. Walaupun demikian, bukan berarti Al Qur'an dan Sunnah semuanya bersifat normatif. Ada beberapa ayat dalam Al Qur'an yang memberi petunjuk-petunjuk praktis dan jelas misalnya pembayaran utang piutang. Bentuk petunjuk praktis ini dapat dibedakan dengan pernyataan normatif dalam Al Qur'an, misalnya tentang sikap pertengahan dalam membelanjakan harta, konsep 
Islamiconomic: Jurnal Ekonomi Islam Vol.7 No.2 Juli - Desember 2016

keadilan dalam perdagangan dan sebagainya yang semuanya memerlukan penjelasan lebih operasioanl dalam sunnah dan selanjutnya ijma, ijtihad dan qiyas.

Terdapat prinsip-prinsip hukum Islam yang lain yaitu Istihsan, Istislah dan Istisha ${ }^{7}$. Istishan merupakan sarana yang yang efektif dalam memasukkan unsurunsur baru dengan tujuan mencari yang terbaik. Istislah berarti melarang atau mengizinkan sesuatu hal karena semata-mata memenuhi "maksud yang baik" (maslahah). Istishab yaitu bila eksistensi sesuatu hal pernah ditetapkan dengan bukti, walaupun kemudian timbul keragu-raguan mengenai kelanjutan eksistensinya, ia masih tetap dianggap ada.

Berbagai masalah dibahas dalam bingkai hukum Islam dari analisa tekstual dan kontekstual Al Qur'an dan Sunnah (hadist), ijma, ijtihad, qiyas sampai kepada penetapan hukumnya. Tetapi sanksi yang dikenakan berdasarkan penetapan hukum tersebut tidak akan memiliki kemampuan mengikat jika tidak disahkan oleh pemerintah sebagai hukum yang berlaku. Pada akhirnya tetaplah hanya berupa sebuah wacana dan sekalipun telah menghasilkan penetapan hukum (halal, haram atau sanksi-sanksi tertentu) hal itu hanya dianggap sebagai sebuah pilihan yang semuanya tergantung pada tingkat keterikatan dan konsistensi setiap pribadi muslim terhadap hukum Islam.

Praktek ekonomi yang berkembang kini semakin luas dan beragam. Karena itu diperlukan aturan-aturan hukum yang baru dan diperbaharui agar dapat mengatasi masalah-masalah ekonomi yang memerlukan penanganan hukum. Hukum akan kehilangan eksistensi dan fungsinya jika tidak mampu mengatasi masalah yang terjadi di masyarakat. Melalui kerangka hukum Islam (sumber-sumber hukum Islam dan metode penetapannya) yang elastis, sebenarnya hukum Islam selamanya tak akan mengalami hal itu. Tetapi jika hukum Islam hanya berhenti pada tingkat wacana dan tidak mendapat pengesahan dari pemerintah, ia tetap tidak akan memiliki kemampuan mengikat yang pada akhirnya hukum Islam tetap kurang memiliki eksistensinya dan fungsinya di masyarakat.

Sebagai sebuah sistem hukum yang memiliki perangkat lengkap sebagai sebuah ilmu yaitu memenuhi aspek ontologis, epistemologis dan aksiologis, ilmu hukum Islam tentunya memiliki kesiapan dalam merespon semua kegiatan manusia, khususnya praktek ekonomi kekinian. Metode ijtihadi memungkin hukum Islam 250 
Wazin: Ekonomi Islam Dalam Kajian...

memberi pandangan dan penetapan hukum terhadap praktek-praktek ekonomi seperti perbankan, jual beli dan sektor jasa.

\section{Relevansi Jaminan Fidusia Dengan Rahn Tasjily}

Produk-produk pemikiran ijtihadi disebut fiqh. Selanjutnya proses penetapan hukum bagi masyarakat Islam tidak terlepas dari aspek fiqh. Dengan konsep ijtihad maka institusi yang belum pernah ada dalam khasanah keilmuan hukum Islam dimungkinkan untuk dikembangkan tanpa bertentangan dengan syari'at Islam, seperti bentuk jaminan fidusia. Jaminan fidusia merupakan kegiatan ekonomi yang berkembang kemudian yang tumbuh karena tuntutan kebutuhan.

Jaminan fidusia adalah hak jaminan atas benda bergerak baik yang berwujud maupun yang tidak berwujud dan benda tidak bergerak khususnya bangunan yang tidak dapat dibebani hak tanggungan sebagaimana dimaksud dalam Undang-undang Nomor 4 Tahun 1996 tentang Hak Tanggungan yang tetap berada dalam penguasaan Pemberi Fidusia, sebagai agunan bagi pelunasan utang tertentu, yang memberikan kedudukan yang diutamakan kepada Penerima Fidusia terhadap kreditur lainnnya. ${ }^{8}$

Jaminan fidusia telah digunakan di Indonesia sejak jaman penjajahan Belanda sebagai bentuk jaminan yang lahir dari yurisprudensi. Bentuk jaminan fidusia dipergunakan secara luas dalam transaksi pinjam meminjam karena proses pembebanannya yang sederhana, mudah dan cepat. ${ }^{9}$ Jadi secara historis jaminan fidusia merupakan produk hukum yang bersumber dari Negara Belanda, yang kemudian diberlakukan di Indonesia sejak jaman kolonialisme hingga kini. Pemberlakuan Undang-undang Nomor 42 Tahun 1999 tentang Jaminan Fidusia dapat dinilai sebagai pemberian fasilitas kemudahan bagi dunia usaha agar lebih berkembang sekaligus menjamin kepastian hukum bagi penyedia dana. Hal ini mengingat benda yang dijaminkan melalui fidusia tetap dapat dipergunakan oleh pemilik benda untuk modal usahanya, dilain pihak Kreditur mendapat kepastian hukum karena dengan setifikat jaminan fidusia Kreditur sebagai Penerima Fidusia memiliki kekuatan eksekutorial yang sama dengan putusan pengadilan jika Debitur atau Pemberi Fidusia cedera janji10. Jaminan Fidusia sering muncul dalam praktek perdagangan dan perbankan sebagai bentuk jaminan dalam perjanjian hutang piutang, permodalan maupun jaminan kredit. Saat ini banyak perusahaan 
Islamiconomic: Jurnal Ekonomi Islam Vol.7 No.2 Juli - Desember 2016

pembiayaan menyelenggarakan kegiatan pembiayaan konsumen yang pada umumnya menggunakan tata cara perjanjian yang mengikutkan adanya jaminan fidusia. ${ }^{11}$

Bagimanakah jaminan fidusia dalam perspektif fiqh mualamah? Kitab muamalah berisi hukum-hukum syari'ah tentang fiqh muamalah. ${ }^{12}$ Adapun fungsi fiqh mumalah adalah untuk mengidentifikasi perintah-perintah syariah dari buktibukti tekstual yang terinci terhadap hukum aktivitas ekonomi. Dengan mengidentifikasi perintah-perintah syari'ah, fiqh muamalah menghasilkan produkproduk hukum-hukum syara' yang bersifat praktis (amaliah) yang diperoleh dari dalil-dalil yang terperinci yang mengatur hubungan keperdataan seseorang dengan orang lain dalam hal persoalan ekonomi, diantaranya: dagang, pinjam meminjam, sewa-menyewa, kerjasama dagang, simpanan barang atau uang, penemuan, pengupahan, rampasan perang, utang-piutang, pengupaham, pungutan, warisan, wasiat, nafkah, barang titipan, pesanan dan lain-lain ${ }^{13}$. Secara lebih singkat dapat dikatakan bahwa fiqh muamalah adalah aturan-aturan Allah yang mengatur hubungan antar manusia dalam memperoleh dan mengembangkan harta benda atau lebih tepatnya aturan Islam tentang kegiatan ekonomi yang dilakukan oleh manusia. ${ }^{14}$

Fiqh muamalah melihat fenomena (ekonomi) dari aspek yang normatif, yakni bagaimana aturan syariah terhadap fenomena tersebut kemudian menetapkan kriteria kebolehan dan larangan tergantung fenomena dan fakta yang dihadapi. Kehidupan ekonomi manusia bersifat dinamis. Perubahan dan pembaharuan dalam bidang ekonomi merupakan tuntuntan yang kodrati. Institusi hukum dalam Islam senantiasa harus mampu menjawab segala perubahan dan pembaharuan tersebut agar tidak kehilangan fungsinya sebagai alat untuk mendukung aktivitas manusia. Insitiusi hukum dalam Islam harus tetap menjalankan fungsinya sebagai pengendali agar setiap muslim tetap berdiri di atas syari'at. Pada garis inilah fiqh muamalah memiliki fungsi penting untuk menafsirkan ayat-ayat Al Qur'an dan hadist untuk menjawab dan memberi solusi atas fenomena-fenmona kegiatan ekonomi ummat Islam.

Ruang lingkup fiqih muamalah meliputi seluruh kegiatan muamalah manusia berdasarkan hukum-hukum Islam yang berupa peraturan-peraturan yang berisi 252 
Wazin: Ekonomi Islam Dalam Kajian...

perintah atau larangan seperti wajib,sunnah,haram,makruh dan mubah. Secara lebih rinci dapat dikatakan bahwa fiqh muamalah merupakan pengetahuan tentang kegiatan atau transaksi ekonomi yang berdasarkan hukum-hukum syariat, mengenai perilaku manusia dalam kehidupannya yang diperoleh dari dalil-dalil Islam secara rinci.

Penetapan hukum suatu kegiatan ekonomi haruslah memenuhi prinsip dasar atau kaidah fiqh muamalah diantaranya adalah:

1. Hukum Asal dalam Muamalah adalah Mubah (diperbolehkan). Ulama fiqih sepakat bahwa hukum asal dalam transaksi muamalah adalah diperbolehkan (mubah), kecuali terdapat nash yang melarangnya. Dengan demikian, kita tidak bisa mengatakan bahwa sebuah transaksi itu dilarang sepanjang belum/ tidak ditemukan nash yang secara sharih melarangnya. Berbeda dengan ibadah, hukum asalnya adalah dilarang. Kita tidak bisa melakukan sebuah ibadah jika memang tidak ditemukan nash yang memerintahkannya, ibadah kepada Allah tidak bisa dilakukan jika tidak terdapat syariat dari-Nya.

2. Konsep Fiqih Muamalah adalah untuk mewujudkan kemaslahatan. Fiqih muamalah akan senantiasa berusaha mewujudkan kemaslahatan, mereduksi permusuhan dan perselisihan di antara manusia. Allah tidak menurunkan syariah, kecuali dengan tujuan untuk merealisasikan kemaslahatan hidup hamba-Nya, tidak bermaksud memberi beban dan menyempitkan ruang gerak kehidupan manusia.

3. Ada 5 hal yang perlu diingat sebagai landasan tiap kali seorang muslim akan berinteraksi ekonomi. Kelima hal ini menjadi batasan secara umum bahwa transaksi yang dilakukan sah atau tidak, lebih dikenal dengan singkatan MAGHRIB, yaitu Maisir, Gharar, Haram, Riba, dan Bathil.15 Maisir sering dikenal dengan perjudian karena dalam praktik perjudian seseorang bisa untung atau bisa rugi. Gharar adalah setiap transaksi yang masih belum jelas barangnya atau tidak berada dalam kuasanya alias di luar jangkauan termasuk jual beli gharar. Haram yaitu ketika objek yang diperjualbelikan ini adalah haram, maka transaksi nya menjadi tidak sah. Riba yaitu penambahan pendapatan secara tidak sah antara lain dalam transaksi pertukaran barang sejenis yang tidak sama kualitas, kuantitas, dan waktu penyerahan. Bathil yaitu 
Islamiconomic: Jurnal Ekonomi Islam Vol.7 No.2 Juli - Desember 2016

Dalam melakukan transaksi, prinsip yang harus dijunjung adalah tidak ada kedzhaliman yang dirasa pihak-pihak yang terlibat. Semuanya harus samasama rela dan adil sesuai takarannya.

Jaminan biasanya berkaitan dengan hutang piutang dan jual beli kredit. Jual beli kredit menimbulkan perjanjian dan perikatan berupa uang muka (urbun) dan jaminan.Tentang jual beli tidak tunai dan jaminan terdapat petunjuk dalam Al Qur'an Surat Al Baqarah (2) ayat 283 sebagai berikut;

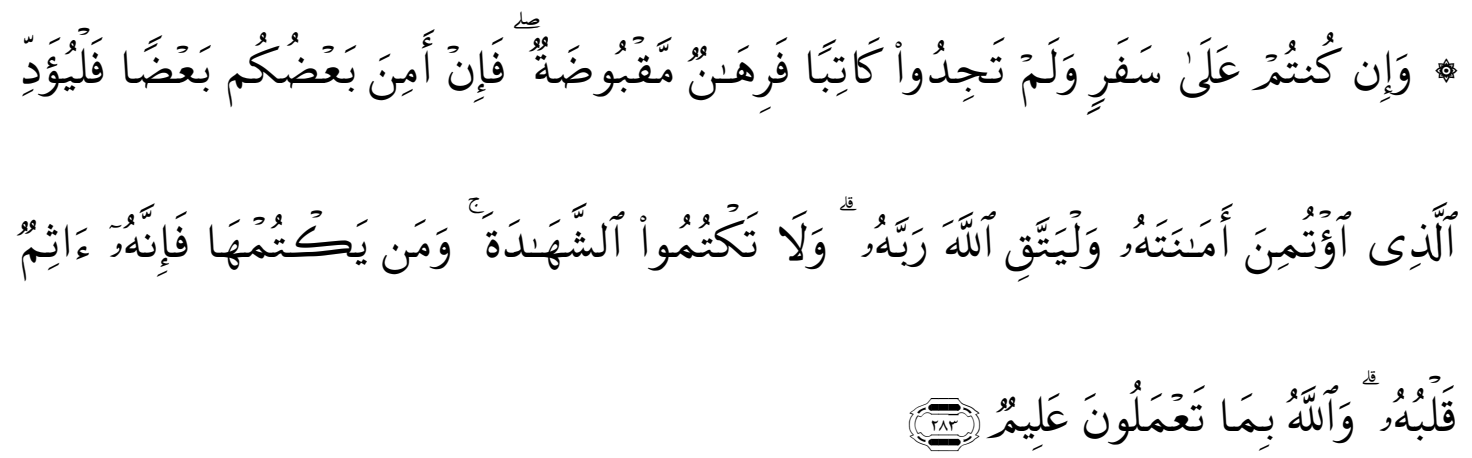

Artinya: Jika kamu dalam perjalanan (dan bermu'amalah tidak secara tunai) sedang kamu tidak memperoleh seorang penulis, Maka hendaklah ada barang tanggungan yang dipegang (oleh yang berpiutang). akan tetapi jika sebagian kamu mempercayai sebagian yang lain, Maka hendaklah yang dipercayai itu menunaikan amanatnya (hutangnya) dan hendaklah ia bertakwa kepada Allah Tuhannya; dan janganlah kamu (para saksi) Menyembunyikan persaksian. dan Barangsiapa yang menyembunyikannya, Maka Sesungguhnya ia adalah orang yang berdosa hatinya; dan Allah Maha mengetahui apa yang kamu kerjakan.

Ayat sebelumnya ditandasi bahwa mu'amalat seyogyanya dilakukan secara tertulis, dan ada saksi supaya tidak terjadi sesuatu hal yang berakibat buruk di kemudian hari. Pangkal ayat Surat Al Baqarah (2) ayat 283 merupakan pengecualian, bagi yang tidak bisa memenuhi ketentuan tersebut, utamanya tatkala di perjalanan. Solusinya ialah yang meminjam hendaknya memberikan jaminan kepada yang berpiutang. Ayat ini memberi isyarat bahwa muamalah tidak tunai tanpa penulis, hanya bisa dilakukan tatkala di perjalanan dan tidak ada penulis. Dengan kata lain, 
Wazin: Ekonomi Islam Dalam Kajian...

selama ada penulis, tetap bukti tertulis mesti ada. Perintah yang tercantum pada ayat sebelumnya (2:282) diserukan kepada orang mu`min. Keimanan mesti dibuktikan dengan pangakuan dan pengamalan. ${ }^{16}$

Perkataan sِ sَseperti tercantum dalam Q.S Al Baqarah (2): 282 menurut bahasa berasal dari هن sang berarti sesuatu yang ditahan, tetap, tidak berubah ${ }^{17}$. Sedangkan menurut istilah syari'ah ialah suatu barang yang dijadikan jaminan sehingga pemiliknya tidak bisa menjual atau menukar dengan lain. ${ }^{18}$ Kalimat (jaminan yang bisa dipegang), terkait dengan tatkala di perjalanan. Secara tersurat, jaminan diperlukan bila utang piutang dilakukan dalam perjalanan. Namun bila kedua belah fihak memerlukan jaminan dalam keadaan muqim (berada di tempat), tetap diperbolehkan demi menjaga kepercayaan dan ketenangan. ${ }^{19}$ Fungsi jaminan, utamanya adalah untuk menjaga kepercayaan bersama, dan pegangan bagi yang punya piutang dari yang berutang 20 .

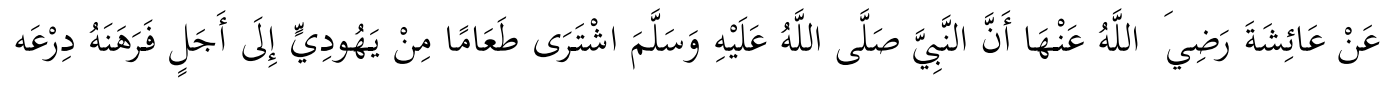

Dari Aisyah diriwayatkan bahwa Rasul SAW membeli bahan pangan dengan menghutang sampai waktu yang ditentukan dengan jaminan baju besinya. HR. alBukhari

Secara umum jaminan dalam hukum Islam (fiqh) dibagi menjadi dua yaitu jaminan yang berupa orang (personal guarancy) dan jaminan yang berupa harta benda. Yang pertama sering dikenal dengan istilah dlaman atau kafalah. Sedangkan yang kedua dikenal dengan istilah rahn. Kafalah menurut etimologi berarti al-dhamanah, hamalah dan za'aamah. Ketiga istilah tersebut memilki arti yang sama, yakni menjamin atau menanggung. ${ }^{21}$ Sedangkan menurut terminologi kafalah adalah jaminan yang diberikan oleh kafiil (penanggung) kepada pihak ketiga atas kewajiban/ prestasi yang harus ditunaikan pihak kedua (tertanggung).

Sebuah hadist menyebutkan: "Pinjaman hendaklah dikembalikan dan yang menjamin hendaklah membayar" (H.R.Abu Dawud). Dengan demikian kafalah dinilai sah menurut hukum Islam jika memenuhi rukun dan syarat yaitu:

1. Kafiil : ( orang yang menjamin), disyaratkan sudah baligh, berakal, tidak dicegah membelanjakan harta (mahjur) dan dilakukan dengan kehendaknya sendiri. 
Islamiconomic: Jurnal Ekonomi Islam Vol.7 No.2 Juli - Desember 2016

2. Makful lah: (orang yang berpiutang/berhak menerima jaminan), syaratnya diketahui oleh orang yang menjamin, ridha (menerima), dan ada ketika terjadinya akad menjaminan.

3. Makful 'anhu (orang yang berutang/ yang dijamin), disyaratkan diketahui oleh yang menjamin, dan masih hidup (belum mati).

4. Madmun bih atau makful bih (hutang/kewajiban yang dijamin), disyaratkan; merupakan hutang/prestasi yang harus dibayar atau dipenuhi, menjadi tanggungannya (makful anhu) dan bisa diserahkan oleh penjamin (kafiil).

5. Lafadz ijab qabul disyaratkan keadaan lafadz menjamin, tidak digantungkan kepada sesuatu dan tidak berarti sementara.

Kafalah dibagi menjadi dua bagian, yaitu kafalah dengan jiwa (kafalah bi al-nafs) dan kafalah dengan harta (kafalah bi al-maal). Kafalah dengan jiwa dikenal pula dengan Kafalah bial-Wajhi, merupakan adanya kesediaan pihak penjamin (al-Kafil, alDhamin atau al-Za'im) untuk menghadirkan orang yang ia tanggung kepada yang ia janjikan tanggungan (Makful lah). Kafalah yang kedua ialah kafalah harta, merupakan kewajiban yang mesti ditunaikan oleh dhamin atau kafil dengan pembayaran (pemenuhan) berupa harta.

Bentuk jaminan lain selain kafalah adalah Rahn. Secara etimologi, kata ar-rahn berarti tetap, kekal, dan jaminan. Akad ar-Rahn dalam istilah hukum positif disebut dengan barang jaminan/agunan.Sedangkan menurut istilah ar-rahn adalah harta yang dijadikan pemiliknya sebagai jaminan utang yang bersifat mengikat. ${ }^{22}$ Berdasarkan definisi yang berasal dari ulama madzhab Maliki tersebut, obyek jaminan dapat berbentuk materi, atau manfaat, yang keduanya merupakan harta menurut jumhur ulama. Benda yang dijadikan barang jaminan (agunan) tidak harus diserahkan secara aktual, tetapi boleh juga penyerahannya secara hukum, seperti menjadikan sawah sebagai jaminan(agunan), sehingga yang diserahkan adalah surat jaminannya (sertifikat sawah). Berbeda dengan definisi di atas, menurut ulama Syafi'iyah dan Hanabilah, ar-rahn adalah:Menjadikan materi (barang) sebagai jaminan utang, yang dapat dijadikan pembayar utang apabila orang yang berutang tidak bisa membayar utangnyanya. ${ }^{23}$

Definisi yang dikemukakan ulama Syafi'iyah dan Hanabilah mengandung pengertian bahwa barang yang boleh dijadikan jaminan(agunan) utang hanya yang 256 
Wazin: Ekonomi Islam Dalam Kajian...

bersifat materi; tidak termasuk manfaat sebagaimana yang dikemukakan ulama madzhab Maliki. Barang jaminan boleh dijual apabila utang tidak dapat dilunasi dalam waktu yang disepakati kedua belah pihak. Dari pendapat madzhab Maliki dimungkinkan bahwa jaminan fidusia merupakan bentuk jaminan yang dibolehkan dalam hukum Islam.

Dewan Syari'ah Nasional (DSN) mengeluarkan fatwa Nomor 68/DSNMUI/III/2008 yang sejalan dengan bentuk jaminan fidusia yang disebut dengan rahn tasjily. Dalam pertimbangannya dinyatakan bahwa bahwa salah satu bentuk jasa pelayanan Lembaga Keuangan Syariah (LKS) yang menjadi kebutuhan masyarakat adalah pinjaman atau transaksi lain yang menimbulkan utang piutang dengan memberikan jaminan barang dengan ketentuan barang tersebut masih dikuasai dan digunakan oleh pihak berutang. Kemudian dinyatakan bahwa pihak berpiutang berhak harus dengan mudah untuk melakukan eksekusi atas barang agunan yang masih dikuasai oleh peminjam jika terjadi wanprestasi.

Rahn tasjily (disebut juga dengan Rahn Ta'mini, Rahn Rasmi, atau Rahn Hukmi) adalah jaminan dalam bentuk barang atas utang, dengan kesepakatan bahwa yang diserahkan kepada penerima jaminan (murtahin) hanya bukti sah kepemilikannya, sedangkan fisik barang jaminan tersebut (marhun) tetap berada dalam penguasaan dan pemanfaatan pemberi jaminan (rahin). Dalam fatwa Nomor 68/DSNMUI/III/2008 terdapat ketentuan khusus yang menyatakan bahwa rahn tasjily boleh dilakukan dengan ketentuan sebagai berikut:

a. Rahin menyerahkan bukti sah kepemilikan atau sertifikat barang yang dijadikan jaminan (marhun) kepada murtahin;

b. Penyerahan barang jaminan dalam bentuk bukti sah kepemilikan atau sertifikat tersebut tidak memindahkan kepemilikan barang ke Murtahin.

c. Rahin memberikan wewenang (kuasa) kepadamurtahin untuk melakukan penjualan marhun, baik melalui lelang atau dijual ke pihak lain sesuai prinsip syariah, apabila terjadi wanprestasi atau tidak dapat melunasi utangnya;

d. Pemanfaatan barang marhun oleh rahin harus dalam batas kewajaran sesuai kesepakatan; 
Islamiconomic: Jurnal Ekonomi Islam Vol.7 No.2 Juli - Desember 2016

e. Murtahin dapat mengenakan biaya pemeliharaan dan penyimpanan barang marhun (berupa bukti sah kepemilikan atau sertifikat) yang ditanggung oleh rahin, berdasarkan akad Ijarah;

f. Besaran biaya sebagaimana dimaksud huruf e tersebut tidak boleh dikaitkan dengan jumlah utang rahin kepada murtahin;

g. Selain biaya pemeliharaan, murtahin dapat pula mengenakan biaya lain yang diperlukan pada pengeluaran yang riil.

h. Biaya asuransi Rahn Tasjily ditanggung oleh Rahin.

Dengan adanya fatwa Nomor 68/DSN-MUI/III/2008 maka jaminan fidusia mendapat keabsahannya dalam perspektif hukum Islam di Indonesia karena hukum asal dari muamalah adalah boleh, dengan catatan harus memenuhi prinsip dasar atau kaidah fiqh muamalah yaitu untuk mewujudkan kemashlahatan ummat dan terhindar dari maisir, gharar, haram, riba dan batil. Untuk itu diperlukan model baru bentuk jaminan fidusia yand relevan dengan kaidah fiqh muamalah, dengan kata lain penerapan rahn tasjily secara lebih konsisten.

\section{Penutup}

Pada dasarnya kerangka hukum Islam selalu siap menghadapi perubahan dalam segala kehidupan, dari aspek etis sampai kepada aturan yang lebih operasional. Tetapi hal ini tidak akan berjalan dengan baik apabila ummat Islam tidak memanfaatkan elastisitas hukum Islam dalam merespon kehidupan ekonomi, politik dan soial yang sedang terjadi. Sifat elastis dari hukum Islam itu sendiri memungkinkan syari'at Islam selalu dapat fungsional bagi kehidupan ummat Islam secara keseluruhan. Akan halnya dengan kegiatan ekonomi, perlu usaha-usaha ijtihad lebih lanjut agar setiap muslim dapat melakukan kegiatan ekonominya sesuai dengan syari'at Islam. Rahn Tasjily yang difatwakan DSN MUI merupakan salah satu usaha ijtihadi yang dapat menjadi solusi bagi masyarakat muslim dalam melakukan transaksi ekonomi dengan menggunakan jaminan, sehingga dibanding dengan jaminan fidusia, praktek rahn tasjily memungkinkan masyarakat terhindar dari praktek ekonomi yang mengandung riba. Para akademisi dan ahli hukum Islam tidak 
Wazin: Ekonomi Islam Dalam Kajian...

boleh berhenti dalam mengkaji kondisi kekinian untuk kembali dirujukkan dengan syari'at melalui usaha ijtihad yang nantinya melahirkan hukum Islam yang mutakhir.

\section{Pustaka Acuan}

Ad-Dardir, 1978, Syarh al-Shagir bi Syarh ash-Shawi, Mesir : Dar al-Fikr.

Ahmad Warson Munawwir, 1997, al-Munawwir Kamus Arab-Indonesia, cet. 14, Surabaya: Penerbit Pustaka Progressif.

As Sarakhsi, tt, al Mabsut, Beirut: Dar al Fikr.

Azharudin Lathif, 2005, Fiqh Muamalat, Jakarta : UIN Jakarta Press.

H. Riduan Syahrani, 2006, Seluk Beluk dan Asas-Asas Hukum Perdata, Bandung: Alumni.

Ibnu 'Abidin, 1963, Radd al-Muhktar 'ala ad-Durr al-Mukhtar, Beirut: Dar al-Fikr.

Ibnu Mandzur, tt, Lisaan Al- 'Arab Jilid I, Kairo: Darul Ma'arif.

Juhaya S. Praja, 2009, Teori Hukum Suatu Perbandingan, Bandung: Tanpa Penerbit.

M Abdul Mannan,1995, Islamic Economics, Theory and Practice (Teori dan Praktek Ekonomi Islam) terj. M Nastangin, Yogyakarta: PT Dana Bhakti Wakaf.

M. Abdul Mujieb,1994, Kamus Istilah Fiqih, Jakarta: Pustaka Firdaus.

UU No. 42 Tahun 1999 Tentang Jaminan Fidusia

Wahbah Zuhaili, 2002, Al-Fiqh al-Islamy wa Adillatuhu, Beirut: Dar al-Fikr.

Zainuddin Ali, 2008, Hukum Ekonomi Syari'ah, Jakarta:Sinar Grafika.

\section{Catatan Akhir:}

${ }^{1}$ Zainuddin Ali, Hukum Ekonomi Syari'ah, (Jakarta:Sinar Grafika, 2008), hlm. 73.

2 Juhaya S. Praja, Teori Hukum Suatu Perbandingan, (Bandung: Tanpa Penerbit, 2009), hlm. 92.

${ }^{3}$ Ibnu Mandzur, Lisaan Al- 'Arab Jilid I,( Kairo: Darul Ma'arif, tt), hal. 3642.

4 Ahmad Warson Munawwir, al-Munawwir Kamus Arab-Indonesia, cet. 14, Surabaya: Penerbit Pustaka Progressif, 1997., hal. 712.

5 Juhaya S. Praja, Op.Cit., hlm. 92.

${ }^{6}$ Dalam M. Abdul Mujieb, Kamus Istilah Fiqih, (Jakarta: Pustaka Firdaus, 1994), hal. 117 tertulis bahwa Ijtihad adalah suatu usaha yang dilakukan para ahli untuk menentapkan suatu hukum, yang dilakukan dengan sungguh-sungguh, mengerahkan segala daya kekmampuan rohani dan akal pikiran yang rasional, maneggali masalah ke-Islaman dengan berdasarkan Al Qur'an dan hadist (Yang Shahih dan Hasan) serta dengan Qias(analogi) yang tepat. Ijtihad merupakan salah satu puncak hukum yang penting dalam perundangan Islam. Hukum yang dapat diijtihadkan adalah yang berhubungan dengan masalah keduniawian yang tidak/ kurang jelas Nashnya dalam Al Qur'an atau Sunnah M. Abdul Mujieb, Kamus Istilah Fiqih, Jakarta: Pustaka Firdaus, 1994), hlm. 117.

${ }^{7}$ M Abdul Mannan, Islamic Economics, Theory and Practice (Teori dan Praktek Ekonomi Islam) terj. M Nastangin, (Yogyakarta: PT Dana Bhakti Wakaf, 1995), hal 38.

${ }^{8}$ UU No. 42 Tahun 1999 Tentang Jaminan Fidusia

${ }^{9}$ H. Riduan Syahrani, Seluk Beluk dan Asas-Asas Hukum Perdata, (Bandung: Alumni 2006), hlm. 148.

${ }^{10}$ UURI No. 42 tahun 1999, Pasal 15 ayat 2. 
${ }^{11}$ Berdasarkan Peraturan Menteri Keuangan (PMK) Nomor 84/PMK.012/2006 tentang Perusahaan Pembiayaan disebutkan bahwa Perusahaan Pembiayan adalah badan usaha di luar Bank dan Lembaga Keuangan Bukan Bank yang khusus didirikan untuk melakukan kegiatan yang termasuk dalam bidang usaha Lembaya Pembiayaan. Dalam Keputusan Menteri Keuangan nomor 448/KMK.017/2000 bahwa Perusahaan Pembiayaan meliputi kegiatan usaha sewa guna usaha, anjak piutan, usaha kartu kredit dan pembiayaan konsumen.

${ }^{12}$ Secara umum pembagian Hukum Islam dibagi menjadi 4 kitab yaitu:

a. Kitab 'Ibadat. Bagian ini membicarakan hukum-hukum bersuci, shalat, zakat, puasa, haji dan segala yang berhubungan dengan masing-masingnya rukun dan syarat serta amal-amal lain seperti azan, iqamat dan sebagainya.

b. Kitab Munakahat. Bagian ini mebicarakan hukum perkawinan, perceraian, ruju', nafkah isteri dan anak, perwalian dan segala sesuatu yang berhubungan dengan akibat perkawinan, juga pembagian harta warisan.

c. Kitab Mu'amalat. Bagian ini mengatur hukum perjanjian, jual beli, gadai dan lain-lain yang menyangkut dengan sosial ekonomi.

d. Kitab 'Uqubat. Bagian yang mengatur hukum pidana, peradilan, urusan pemerintahan, hubungan dengan luar negeri, perang dan damai, pemberontakan, pindah agama, kewarganegaraan dasn sebagainya.

${ }^{13}$ Zainuddin Ali, Op.cit., hlm. 119.

${ }^{14}$ Adapun ruang lingkup muamalah mencakup segala aspek kegiatan ekonomi manusia sebagai berikut:Harta milik, Ba'yu (tentang jual beli), Ar Rahn (gadai), Hiwalah (pengalihan utang), Ash-Shulhu (perdamaian bisnis), Adh Dhaman (jaminan, asuransi), Syirkah (tentang perkongsian), Wakalah (tentang perwakilan), Wadi'ah (tentang penitipan), 'Ariyah (tentang peminjaman), Ghasab (perampasan harta orang lain dengan tidak sah), Mudharabah (syirkah modal dan tenaga), Musaqat (syirkah dalam pengairan kebun), Muzara'ah (kerja sama pertanian), Kafalah (penjaminan), Taflis (jatuh bangkrut,), Al-Hajru (batasan bertindak,), Ji'alah (sayembara, pemberian fee), Qaradh (pinjaman), Ba'i Murabahah, Ba'i Salam, Ba'i Istishna', Ba'i Muajjal dan Ba'i Taqsith, Ba'i Sharf dan transaksi valas'Urbun (panjar/ DP), Ijarah (sewa menyewa), Riba (konsep uang dan kebijakan moneter)Shukuk (surat utang atau obligasi)Faraidh (warisan)Luqathah (barang tercecer), WaqafHibahWasiatIqrar (pengakuan), Qismul fa'i wal ghanimah(pembagian fa'i dan ghanimah), Qism As-Shadaqat (tentang pembagian zakat), Ibrak (pembebasan utang), Muqasah (discount), Kharaj, Jizyah, Dharibah dan UshurBaitul Mal dan Jihbiz, Kebijakan fiskal Islam Prinsip dan perilaku konsumen, Prinsip dan perilaku prosusen, Keadilan distribusi, Perburuhan (hubungan buruh-majikan, upah buruh), Jual beli gharar, ba'i najasy, ba'i al-inah, ba'i wafa, mu'athah, fudhuli dan lain-lain. Reksadana, Asuransi Islam, pegadaian, Bank Islam, MLM dan lain-lain

${ }^{15}$ ]Azharudin Lathif, Fiqh Muamalat, (Ciputat : UIN jakarta Press, 2005), cet.1, hlm. 5.

16 Al-Margahi (1365H), tafsir al-Maraghi, III hlm.78.

${ }^{17}$ Ibn Manzhur, Lisan al-Arab, XIII hlm.189.

18 Manshur Ali Nashif, al-taj al-Jami li Ushul ahadits, II hlm.651.

${ }^{19}$ Wahbah al-Zuhayli, al-tafsir al-Munir, III hlm.122.

${ }^{20}$ Ibid.

${ }^{21}$ Wahbah Zuhaili, Al-Fiqh al-Islamy wa Adillatuhu, (Beirut: Dar al-Fikr, 2002), cet. 6, hlm. 414

22 Ad-Dardir, Syarh al-Shagir bi Syarh ash-Shawi, (Mesir : Dar al-Fikr, 1978), Jilid III, hlm. 303.

${ }^{23}$ Ibnu 'Abidin, Radd al-Muhktar 'ala ad-Durr al-Mukhtar, (Beirut: Dar al-Fikr, 1963), Jilid V, hlm. 339, lihat juga As Sarakhsi, al Mabsut, (Beirut: Dar al Fikr, tt.), Jilid XXI, hlm. 63. 